\title{
Developing English Materials for Nursing Students of SMK Kesehatan Bali Medika Denpasar
}

\author{
I G. Aris Pratama Putra ${ }^{1}$, N.N. Padmadewi ${ }^{2}$, I G. Budasi ${ }^{3}$ \\ ${ }^{123}$ English Language Education, Post Graduate Program, Universitas Pendidikan Ganesha, Singaraja \\ e-mail: pratama.putra, nym.padmadewi ${ }^{1}$, gede.budasi $\left.{ }^{2}\right\} @$ pasca.undiksha.ac.id
}

This study aimed at analysing materials needed for nursing students of SMK Kesehatan Bali Medika Denpasar; developing materials for teaching English for nursing students of SMK Kesehatan Bali Medika Denpasar; analysing the quality of the developed materials for teaching English for nursing students of SMK Kesehatan Bali Medika Denpasar as perceived by expert judges. This study used $R$ \& $D$ model proposed by Sugiyono (2013), in which the procedures were initiated by an identification of potency \& problem. To analyze target and learning needs of English for nursing students, Hutchinson \& Waters's Learning-Centered Need Analysis Framework (1987) was employed. The present study was limited into developing the product and expert judgment. Therefore, the field test was not conducted in the present study. Every unit of developed materials is presented in a consistent format, comprising input, content focus, language focus, and task. The findings of this study showed that there were 8 units of English for nursing students' materials that need to be developed. Those were; (1) Introduction; (2) Giving Directions in Hospital; (3) Health Problems; 4) Types of Symptoms; 5) Diagnosing Patient's Problems; 6) Discussing Observation; (7) Assessment; (8) Patient Assessment. The materials were focused on developing the students' speaking ability. The quality of the product very good (Product Quality $=4.13$ ) and had met the criteria of material and categorize as very good, which means that these materials are ready for use in the school.

\section{Keywords: English materials, nursing students}

\section{INTRODUCTION}

English as an International language is used as instructional language of scientific study, economy and business, technology information, and others. English is the language of globalization, international communication, and commerce. Learning English as an International language is very important for people who want to expand relations with those who come from other countries and also we can communicate effectively with other people around the world. English is used as communication tool. Therefore, it makes the mastery of English very essential. It is now becoming a necessity to have effective communication skills and resources, so that's why many people interest to learn English. In Indonesia English is the first foreign language, which is taught as a compulsory subject in the school, from the elementary school until university level. As a compulsory subject, students should master English if they want to pass the final exam. Harmer (2003:70) asserts that for many years communication was seen as a supplementary to the main purpose of language teaching namely the acquisition of grammatical knowledge about the language.

In studying English, students should master the four language skills, namely listening, speaking, reading, and writing. Speaking is one of four skills needs to be developed by the students. It is because speaking has a big role in conversation. By mastering the skill people can carry out conversation with others, give the ideas and exchange the information, especially for students who will use English in specific purposes of speaking like hospitality, medical sector, business, etc. By mastering English for specific purpose, the English learners will be able to communicate their ideas in the form of specific purposes. Learners can explore their thoughts and inspiration which are communicated into a specific aspect.

Nowadays, along with the strengthening position of English as a language for international communication, teaching of English for specific purposes has become 
increasingly important. Due to the large number of students who want to study English in order to be able to use English for communicative purposes, the teaching of English for specific purposes is very important. This is apparent in Richards and Renandyas (2002) publication where they stated, a large percentage of the world's language learners study English in order to develop proficiency in speaking. English is not only taught ad learned, but it is used as a habit.

There are many discussions about the level of Indonesian students speaking proficiency and the ability of English for specific purposes in the literature concern, the result showed that Indonesian students commonly do not have a good level ability of oral English proficiency.

Those problems that happen in Indonesia, specially happen in SMK Kesehatan Bali Medika Denpasar too. From the preliminary observation that has been done by the researcher, students of SMK Kesehatan Bali Medika Denpasar were found to have a low ability to speak English, especially English that will be used in the hospital to handle patient. That problem happens because the Indonesian National Syllabus does not focus provide English used in the hospital, And also from the interview with the English Teachers in SMK Kesehatan Bali Medika Denpasar.

As one of the institutions of education that focus preparing qualified human resources in the field of medical sector that located in Cargo Sari Dana Street, this school produces professional output by equipping the students with some subjects related to medical sector need. One of the subject is English which is taught for each grade of student to build all professional students to be ready to enter the globalization era.

To achieve the output standard competencies above and to be able to produce qualified human resources in this sector, the school should also provide the English teacher who is good mastering English for nursing program with the syllabus and material for their teaching.

According to Nunan (1988), Syllabus design covers to selection and grading of content, while methodology deals with selection of learning task and activities. Those to adopt a broader view question this strict separation, arguing that with the advent of communicative language teaching the distinction between content and tasks is difficult to sustain. The following quotation has been taken from Cadlin (1984) which provides an overview of the range and diversity of opinion on syllabus design. It is stated that:

Syllabuses are concerned with the specification and planning of what is to be learned, frequently set down in some written form as prescription for action by lecturers and learners. They have, traditionally, the mark of authority. They are concerned with the achievement of end, often, though not always, associated with the pursuance of particular means (Candlin, 1984).

Syllabus means a learning plan on a subject matter/ specific theme and/ or a group of subject matter /specific theme that covers competency standard, basic competencies, subject material, learning material, learning activities, indicators, assessment, time allocation and source/ material/ instrument of learning (BSNP:2006). It is detailed explanation of competency standards and basic competencies that are realized into subject matter/learning materials, learning activities and assessment indicators or competency achievement. at the end of learning the students are hoped to master a set of competence in own self ( attitude, skill, knowledge, capability, personality, principles, values, interest and conviction); passing process of active, creative, pleasant, and effective learning that could be used for their future.

To make a successful learning, this syllabus needs to be equipped with a good learning material. O'Neil (1990) argues that materials may be suitable for students' needs, even if they are not designed specifically for them, the textbooks make it possible for students to review and prepare their lesson that text books are efficient in term of time and money and that text books can and should allow for adaptation and improvisation.

However, the expectation above contrasts with the reality which happens at SMK Kesehatan Bali Medika which already discussed above. Based on some reflection in teaching and text books analysis it was found out that they use a text books which some of the material are not support to communicative for nursing program. One of the examples is the text books give a lot of definition of tenses and some of texts but less of the dialogue that the students 
need to communicate to other especially in medical sector and need a lot of medical vocabularies.

Learning material is the source as well as guidance for the students; the effectiveness of the material can be identified by considering their practicality, compatibility, and usefulness. Thus, all material practices and exercises should be properly designed in order to be highly functional, easy to be applied, match with standard of competencies, basic competencies and indicators stated in the school syllabus and curriculum, and beneficial for the students' future life.

Due to the needs of the students at this school, then it is important that they are provided with special English teaching materials that concentrate on their expertise program. In order words, the students should be taught by using English materials which are useful, contextual, highly functional and easy to be applied.

Considering the importance of specific learning material for English subject in SMK Bali Medika Denpasar and the lack of such kind materials, the need to develop learning materials for teaching English for specific purpose at this school is highly required to develop a new material developing material, a research about the students' need and an analysis about the existing material. The result of the research is used as guideline. This kind of research is known as Research and development (R\&D).

\section{RESEARCH METHOD}

The present study was used Sugiyono's Model of R \& D (2013). Step 1 (identifying the potency \& problem phase or need analysis phase) of Sugiyono Model of R\&D Design used Hutchinson \& Waters's Learning-Centered Need Analysis Framework (1987) because Hutchinson \& Waters's Learning-Centered Need Analysis Framework was more comprehensive than Sugiyono's. It was used to analyze target needs and learning needs of English for nursing. The present study was limited into developing the product and expert judgment. Therefore, the field test was not conducted in the present study. The material of English for nursing was developed by using the model of ESP material design of Hutchinson and Waters (1987:108) which consists of input, content focus, language focus, and task. The materials were evaluated using the criteria of material evaluation checklist proposed by McDonough et al (2013).

The present study was conducted in SMK Kesehatan Bali Medika Denpasar in order to find the needs and interest of the students. Furthermore, the present study was also conducted in Wangaya Hospital in order to know the target needs regarding the job description of the nursing.

Since need analysis was conducted to identify the learners' needs, the students of nursing department were used as the main subjects of this study. Their needs and problem relating to English for nursing were gathered and analyzed. Nursing officer and English instructor was also used as the subjects of the present study.

The object of the study was English for nursing material. In order to develop English for nursing material, the researcher conducted need analysis to analyze the target need at hospital industry and learning need at XI grades students of SMK Kesehatan Bali Medika

There data analysis which were used in this study namely qualitative data analysis. The step of data analysis can be seen as follows. Firstly, the data were taken from observation, interview, document-study and checklist instrument were qualitatively analyzed. The data were analyzed using the data analysis technique of Miles and Huberman in Sugiyono (2013:340). Firstly, the raw data were narrated in the field note. The next step is data reduction in which the data were redacted and categorized according to the category: 1) Target Needs (task and competencies required), 2) Learning Needs (2.a. students' profile; and 2.b. SMK Kesehatan Bali Medika Denpasar needs \& resources related to the course) the next step was data display in which the data were presented into patterns. The last step was conclusion drawing or verification in which the important data would be concluded to be used to formulate the hypothesis of the drafts materials and the unimportant data would be leaved out. The hypothesis of the drafts materials was used to make the draft of English for nursing course materials. 
After the draft of materials had been designed, the draft was sent to expert judges Dr. Luh Putu Artini, M.A. and Dr. Dewa Putu Ramendra, S.Pd., M.Pd, in order to know to what extend is the quality of developed materials for teaching English for Nursing of students of SMK Kesehatan Bali Medika Denpasar. For getting information about the quality of developed materials, the results of data were calculated and classified into some categories. The categories were determined by using the following mean formula (See Table 1):

Table 1: The formula of categorization of the data

\begin{tabular}{|c|c|}
\hline Score & Categories \\
\hline 4.01 to 5.00 & Very Good \\
\hline 3.01 to 4.00 & Good \\
\hline 2.01 to 3.00 & Average \\
\hline 1.01 to 2.00 & Poor \\
\hline 0 to 1.00 & Very Poor \\
\hline
\end{tabular}

Where

$$
M=\frac{\sum X_{i}}{N}
$$

$\mathrm{X}_{\mathrm{i}}=$ each of the score in turn

$\mathrm{N}=$ the total number of scores in the distribution

(Adapted from Hinkle et all, 1979:37)

\section{FINDINGS AND DISCUSSION}

THE PROCESS OF DEVELOPING ENGLISH TEACHING MATERIALS FOR NURSING STUDENTS OF SMK KESEHATAN BALI MEDIKA DENPASAR

The research and development model proposed by Sugiyono was modified into six main steps. The steps involved in this study were Problem Identification, Data Collection, Product Design, Design Validation, Revision, and Final Product.

1). Problem Identification

The researcher started the study by identifying the study by identifying problems. Problem identification was done by observing and analyzing curriculum syllabus and existing reading material materials used by senior English teacher and the students. After conducting observation, the researcher found that:

a. SMK Kesehatan Bali Medika Denpasar uses the text book and syllabus supplied by government

b. There is no specific English material for nursing

c. Students in SMK Kesehatan Bali Medika Denpasar study general English for their English lessons in the classroom

d. Students in SMK Kesehatan Bali Medika Denpasar are not familiar with expressions that is used in nursing practice

e. Students in SMK Kesehatan bali Medika Denpasar need English learning materials that is focused to explain English for nursing

2). Data Collection 
After the researcher found the problem then gathered the information from administration of questionnaire, interview, and document study which were used as data to design English materials for XI class of SMK Kesehatan Bali Medika Denpasar as a product.

\section{a. Questionnaires}

Target needs questionnaire and learning needs questionnaire were kinds of questionnaires that were used to collect the data. Target needs questionnaire was distributed to the nursing officer used to identify skills and knowledge needed to function in the target situation.

While, learning needs questionnaire was distributed to the students in SMK Kesehatan Bali Medika Denpasar used to identify attitudes/wants/potential of learners and to identify needs /potential/ constraint of learning/teaching situation. The function of learning needs questionnaire was to know theoretical views of learning and analyze learning situation in SMK Kesehatan Bali Medika Denpasar.

b. Interview

Comprehensive interview was done to collect the data for making the design of the product. Interview was conducted to the head master of SMK Kesehatan Bali Medika Denpasar and the nursing officer in the hospital. Interview with the head master of SMK Kesehatan Bali Medika Denpasar was for knowing learning needs of students and interview with nursing officer in hospital was to know target needs in the medical field.

The head master of SMK Kesehatan Bali Medika Denpasar, Drs, Gde Rimaya, DMM said that nursing students needed to study English for nursing materials because it was important for them, but there was no English teaching materials supplied by government for medical vocational high school. He said he wanted the output of SMK Kesehatan Bali Medika Denpasar have an English language competency because it is helpful them to find job in medical field and can improve the prestige of the school.

Based on the interview with the nurse officer in Wangaya hospital, Ns. I Gusti Ayu Dewi, it can be concluded that English for nursing was very important because sometimes nursing officer got foreign emergency patient. She added "In Wangaya hospital rarely get foreign patient, foreign patient usually choose international hospital like Siloam Hospital or Bali Med Hospital".

\section{3). Product Design}

The draft of the material English for nursing department students was developed from the profile of Target Needs Analysis and the profile of learning needs data analysis. There are two drafts of materials design development for nursing department program at SMK Kesehatan Bali Medika Denpasar. The first materials draft was based on target need data reduction. The second materials draft was based on learning need data reduction. Based on the profile of target needs, the draft of materials design should contain 10 tasks as follows:

1. Handling patient's consultation in English

2. Checking patient condition

3. Giving information to patient in English

4. Coordinating to other department in English

5. Preparing patient's medical report in English

6. Connecting the patient's call in English

7. Handling check in and check out patient in English

8. Giving hospital information and facilities in English

9. Reading and understanding report about hospital in English

10. Filling medical form in English

On the other hand, based on the profile of learning needs, the materials draft which should be developed was English for nursing department purposes which would be used in hospital. The material also needed to focus on developing the speaking ability of the students. In addition, the researcher should develop the material draft based on nursing standard competencies which contained the following materials bellow:

1. Conducting interpersonal communication in implementing nursing procedure 
2. Applying the principles of ethics in nursing

3. Applying the principles of nosocomial infections.

4. Take actions of the needs of personal hygiene.

5. Take actions of the needs of environmental cleanliness

6. Conducting treatment after the client / patient died

7. Installing jar of hot and iced wineskins

8. Measuring vital signs

9. helping urination and defecation of patients in bed

10. Giving a cold and warm compress

11. Fed and watered the patient through the mouth

12. Transferring patients from bed to brankard and vice versa

13. Mobilizing the client / patient sloping

In conclusion, the researcher synthesized the findings of target and learning needs data redaction. The researcher should develop more material which focuses on developing students' speaking ability. In other words, the materials would be designed into 8 units.

4). Design Validation

Design validation is a process to measure the product design which was designed by the researcher. In this step, the researcher validated the design by bringing out the experts to measure the product.

After being judged by two experts namely Dr. Luh Putu Artini, M.A. and Dr. Dewa Putu Ramendra, S.Pd., M.Pd, the draft of the materials still covered 8 units. The materials were still designed by following the model of ESP material design of Hutchinson and Waters (1987:108) which consists of input, content focus, language focus, and task.

The input still contained introductory picture with some questions as stimulus material for activities, new language items, correct models of language use, a topic for communication.

On the other hand, Content focus still contained non-linguistic content in the form of reading passage. The function was to teach the student the theory of the topic; therefore, the students could generate meaningful communication in the classroom. Content focus also contained reading comprehension question in the form of True and False exercise. The function was to check the students whether they have understood the reading passage or not.

On the other hand, Language focus contained common language expressions of English for nursing students. The function was to encourage learners use language accurately and introduce the learners to the common language expressions of English for nursing.

On the other hand, the Task still contained communicative task in which learners use the content and language knowledge they have built up through the unit. Controlled Practice aimed to develop the specific lexis of nursing and the students' speaking ability and writing ability

5). Design Revision

After the experts measured the design, it was found some weaknesses of the product. Then it would be revised the design by the researcher. For the revising it based on the weaknesses found after validated by the expert judges.

6). Final Product

After revising the product, the final product was ready to be used as an English teaching material.

\section{KIND OF MATERIALS SHOULD BE DEVELOPED FOR TEACHING ENGLISH FOR} NURSING COURSE AT SMK KESEHATAN BALI MEDIKA DENPASAR

1) The material contained 8 units

Theoretically, Nursing staff is the one who works in the hospital whose duties are 1) conducting interpersonal communication in implementing nursing procedure; 2) applying the principles of ethics in nursing; 3) applying the principles of nosocomial infections; 3) take actions of the needs of personal hygiene; 4) take actions of the needs of environmental cleanliness; 5) conducting treatment after the client / patient died; 6) installing jar of hot and iced wineskins; 7) measuring vital signs; 8) helping urination and defecation of patients in bed; 9) giving a cold and warm compress; 10) fed and watered the patient through the mouth; 11) 
transferring patients from bed to brankard and vice versa; 12) mobilizing the client / patient sloping. In addition, nursing staff should also have a good personality and ability to speak foreign languages in order to support his or her carrier in the hospital. Therefore, English for nursing material should accommodate 13 tasks of nursing staff proposed by national nursing standard competencies.

Furthermore, based on the findings of the study, the materials contained 8 topics as follows: 1) Introduction; 2) Giving Direction in Hospital; 3) Health Problems; 4) Types of Symptoms; 5) Diagnosing Patient's Problems; 6) Discussing Observation; 7) Assessment; 8) Patient Assessment. Each topic can have a number of subtopic. Some of 13 tasks as proposed by national nursing standard competencies were inserted to the 8 topics. In short, the current topic of English for nursing supports the profile of nursing national standard competencies.

2) The material focused on teaching speaking ability.

As it can be seen from the need analysis findings, nursing job demanded speaking skill more at workplace than other skill. Therefore, English for nursing material contained more speaking practice material in order to give the student more practice in speaking.

3) The material should promote some of learning activities

Need analysis findings showed that the materials should promote one of the learning activities such as hand-on activities (for example role play), watching video, learning by solving the problem, seeing power point slide show, and learning by picture strip story because the students enjoyed learning by those learning activities. The current material of English for Nursing used more hand-on activities, namely role play, and simulation because the students enjoyed learning by those learning activities.

4) All units from Unit 1 to Unit 8 used the model of ESP material design of Hutchinson and Waters (1987:108)

Theoretically, the model of ESP material design of Hutchinson and Waters (1987:108) consists of input, content focus, language focus, and task. Input can be in the form of a number of things such as stimulus material for activities, new language items, correct models of language use, a topic for communication. This could be a text, dialogue, video-recording, diagram or any piece of communication data, depending on the needs which have defined in the analysis. The present input of the material of English for Nursing Course draft used picture with some questions. The use of picture or other realia can support the language acquisition of the students (Krashen, 1982:66). Therefore, the design of input of the material of English for Nursing is consistent with the theory stated in review of the related literature, proposed by Krashen (1982:66) who states that the use of picture or other realia can support the language acquisition of the students

Content focus is non-linguistic content which functions to generate meaningful communication. The present content focus of the material of English for Nursing Course draft used familiar reading passage. The topic of reading passage was taken from a number of resources such as Nursing Standard Operational Procedure, nursing Job Desk and internet. The comprehension of reading passage was checked by the use of True and False (T/F) exercise. The reason of using reading passage is to teach the student the theory of the topic; therefore, the students could generate meaningful communication in the classroom. Reading Passage also can take advantage of the student's knowledge of the world in helping comprehension by discussing topics which are familiar to the students. Krashen (1982:66) states that discussing or reading about a topic which is totally unknown will make the message harder to understand. Therefore, the researcher designed the reading passage with familiar things regarding Nursing department. It also functioned to encourage the students to learn something they wanted to read about because they were interested in being Nursing Staffs; therefore, the researcher designed the reading passage about nursing department. Consequently, the design of content focus of the material of English for Nursing is consistent with the theory stated in review of the related literature, as proposed by Krashen (1982:66) who states that discussing or reading about a topic which is totally unknown will make the message harder to understand.

On the other hand, Language Focus functioned as enabling learners to use language accurately. In order to encourage learners use language accurately, the materials should equip 
the learner with enough of the necessary language knowledge. The present content focus of the material of English for Nursing Course draft contained Nursing language expression in order to equip the learner with enough of the necessary language knowledge. Therefore, the design of language focus of the material of English for Nursing is consistent with the theory stated in review of the related literature, proposed by Hutchinson and Waters (1987:108-109) who states that Language Focus should contain enough of the necessary language knowledge to enable learners to use language accurately.

Last but not the least, Task functioned as leading learners towards a communicative task in which learners use the content and language knowledge they have built up through the unit. The ultimate purpose of task is to use language communicatively. Controlled Practice functioned as teaching the learners correct habits of language use. In other words, the researcher expects the learners to master the standard language of nursing language expression since hospital authorities expect the learners to be able to use polite standard language when they work at nursing department. Correct habits of language use can be taught by dialogues, drilling, repetition, memorization and a number of repeated exercises (Richards and Rodgers, 1986:53). Therefore, the current draft of Controlled Practice contained Speaking and Writing Practice with a number of repeated exercises.

Therefore, the design of Task is consistent with the theory stated in review of the related literature, as proposed by Hutchinson and Waters (1987:108) and Richards and Rodgers (1986:53).

THE QUALITY OF THE DEVELOPED MATERIALS FOR TEACHING ENGLISH FOR NURSING COURSE AT SMK KESEHATAN BALI MEDIKA DENPASAR AS PERCEIVED BY EXPERT JUDGES

The result of the expert judgment showed that the product quality was very good. (Product Quality $=4.13$ ). Therefore, the product mets the criteria of material evaluation checklist proposed by McDonough et al (2013) as stated in review of the related literature. The result of expert judgment also contributes the field of ESP because there were limited studies conducted to evaluate English for nursing material. The study also contributes as a reference for other researchers who are concerned in the same or similar study.

\section{CONCLUSION AND SUGGESTIONS}

Considering the background of the studies, review of related literature, relevant empirical evidence, findings, and discussion stated briefly explained in the previous chapters, several conclusions could be drawn as follows:

1) There were 8 units of English for Nursing material had been developed in this present study using the model of ESP material design of Hutchinson and Waters (1987:108). Those were; (1) Introduction; (2) Giving Directions in Hospital; (3) Health Problems; 4) Types of Symptoms; 5) Diagnosing Patient's Problems; 6) Discussing Observation; (7) Assessment; (8) Patient Assessment.

2) The quality of the product of English for Nursing Course was very good (Product Quality = 4.13) and had met the criteria of material evaluation checklist proposed by McDonough et al (2013). However, there were some of the things which should be revised and developed in the materials in order to be better than the first draft of the material of English for Nursing Course

In line with the result of this research, there are some suggestions formulated as follows:

1) The product of this research needs to be further analyzed and reconstructed for the betterment of this product.

2) The field test toward the product of this research should be conducted in order to ensure the effectiveness of this product.

3) Further research on comparing and constructing this product with other existing and competitive ones are highly recommended.

Another educational research genre (e.g. action-based and experimental research) is also recommended to be conducted since there are still many problems to be researched and solved regarding the findings of this research. 


\section{REFERENCES}

2006. Standard Kompetensi dan Kompetensi dasar SMK/MAK. Jakarta:

Badan Standard Nasional Pendidikan.

Alexander, N.P. 1999. Understanding adults as learners. Child Care Information Exchange, 11, 82-84.

Baltes, P.B. (1987). Theoretical propositions of life-span developmental psychology: On the dynamics between growth and decline. Developmental Psychology, 23, 611-626.

Basturkmen, H. 2010. Developing Courses in English for Specific Purposes. New Zealand: Palgrave Macmillan

Bierema, L.L. and Merriam, S.B. 2014. Adult Learning: Linking Theory and Practice: San Francisco: Jossey-Bass

Celce-Murcia, M.. 2001. Teaching English as a Second or Foreign Language: Third Edition. USA: Heinle \& Heinle

Dambayana, Putu Eka. 2010. Developing English Writing Materials for the Seventh Year Students of SMP Negeri 2 Singaraja, Bali in the Academic Year 2009/2010: A Desciptive Qualitative Research and Development. Unpublised Thesis, Singaraja: UNDIKSHA

Dewi, Kadek Yati Fitria. 2010. Developing English Writing Materials for the Seventh Year Students of SMP Negeri 2 Singaraja in the Academic Year 2009/2010Unpublised Thesis, Singaraja: UNDIKSHA

Dudley-Evans, T., and St John, M.J. 1998. Developments in English for Specific Purposes: A multi-diciplinary approach. United Kingdom: Cambridge University Press

Frendo, E. 2005. How to Teach Business English. England: Pearson Education Limited.

Galbraith, D.D and Fouch, S.E. 2007. Principles of Adult Learning: Application to safety training. Retrieved from http://www.vista-training.com/assets/pdf/principles-adultlearning.pdf

Hinkle, D.E., Wiersma, W., and Jurs,S.G. 1979. Applied Statistics for the Behavioral Sciences. USA. Houghton Mifflin Company.

Hornby, A.S. 2010. Oxford Advanced Learner's Dictionary: Eight Edition. New York: Oxford University Press.

Hutchinson, T., and Waters, A. 1987. English for Specific Purposes: A learning-centred approach. United Kingdom: Cambridge University Press.

Krashen, S. D. 1982. Principles and Practice in Second Language Acquisition. USA: University of Southern California.

Mc Donough, J., Shaw, C., and Masuhara, H. 2013. Materials and Methods in ELT: Third Edition. United Kingdom: Wiley-Blackwell Publishing. 
Rahimy, R. ,and Samaneh Safarpour, S. 2012. The Effect of Using Role-Play on Iranian EFL Learners' Speaking Ability. Retrieved from http://www.ajssh.leenaluna.co.jp/AJSSHPDFs/Vol.1(3)/AJSSH2012(1.3-06).pdf

Richards, J.C. 2001. Curriculum Development in Language Teaching. USA: Cambridge University Press.

Richards, J.C., and Rodgers, T.S. 1986. Approaches and Methods in Language Teaching. USA: Cambridge University Press.

Richards, J.C., and Schmidt, R. 2002. Longman Dictionary of Language Teaching and Applied Linguistics. London: Longman.

Sugiyono. 2013. Metode Peneilitian Pendidikan: Pendekatan Kuantitatif, Kualitatif, dan R\&D. Bandung: Alfabeta.

Tomlinson, B. 1998. Materials Development in Language Teaching. United Kingdom: Cambridge University Press.

Tomlinson, B. 2013. Developing Materials for Language Teaching: Second Edition.India:

Bloomsbury. 